\section{Primary prevention: exposure reduction, skin exposure and respiratory protection}

\author{
Dick Heederik*, Paul K. Henneberger" and Carrie A. Redlich ${ }^{\S}$ on behalf of the ERS \\ Task Force on the Management of Work-related Asthma ${ }^{+}$
}

ABSTRACT: Interventions for the primary prevention of occupational asthma have been reported in the medical literature, understanding the effectiveness of these efforts could help future interventions.

The aim of our study was to evaluate the existing knowledge regarding the impact of controlling work exposure on the prevention of occupational asthma. We conducted systematic literature searches through April 2010 to examine if control of workplace exposures is effective for primary prevention of sensitisation and occupational asthma.

The literature search for primary prevention of occupational asthma yielded 29 studies. Assessment of the available information led to the following conclusions and recommendations concerning primary prevention of occupational asthma. Exposure elimination is the strongest and preferred primary preventive approach to reduce the burden of occupational asthma. If elimination is not possible, exposure reduction is the second best option for primary prevention of occupational asthma.

The evidence for the effectiveness of respirators in preventing occupational asthma is limited, and other options higher in the list of controls for occupational exposures, notably eliminating or minimising exposures at the source or in the environment, should be used preferentially. There is strong evidence to recommend not using powdered allergen-rich natural rubber latex gloves. There is weak evidence that suggests workers should minimise skin exposure to asthma-inducing agents.

KEYWORDS: Asthma, exposure reduction, occupational asthma, primary prevention, respiratory protection

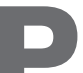

rimary prevention of occupational asthma involves reducing exposure so that susceptible workers do not develop disease. In practice, the prevention of occupational asthma is often challenging, but still attainable. Control of exposure can be achieved by different control measures and a hierarchical strategy is commonly applied (table 1). The preferred measure is substitution of an agent, for instance, substitution of enzymes with strong sensitising potential by less strong sensitising enzymes, or a change to a process that does not require the use of enzymes at all. When substitution is not possible, exposure reduction is the next best approach. Exposure reduction can be achieved by reducing the source strength (i.e. amount or concentration emitted), modifying the formulation of the active ingredient (e.g. liquid or granule instead of powder), changing the process, or by improving general hygiene (good housekeeping). Other options are isolation of the source (enclosure or segregation), ventilation, avoidance of exposure, and use of personal protective equipment (PPE). Often, optimal exposure reduction strategies consist of a combination of technical and organisational measures. In practice, exposure reduction relies on a combination of different interventions. Latex is an exceptional example, where considerable exposure reduction is achieved by using nonpowdered instead of powdered gloves.

It is important to define a desirable exposure reduction, and exposure standards can play an important role in this process. Exposure standards proposed by the European Union Scientific Committee on Occupational Exposure Limits are legally binding for all Union member states or national standard setting bodies. These standards are based on generally accepted and transparent risk assessment principles. Professional organisations in

\section{AFFILIATIONS}

*Division of Environmental Epidemiology, Institute for Risk Assessment Sciences, University of Utrecht, Utrecht, The Netherlands. \# National Institute for Occupational Safety and Health, Centers for Disease Control and Prevention, Morgantown, WV, and

'Yale University, Occupational and Environmental Medicine Program, New Haven, CT, USA.

+For a full list of the members of the Task Force please see the Acknowledgements.

\section{CORRESPONDENCE}

D. Heederik

Division of Environmental

Epidemiology, Institute for Risk

Assessment Sciences

University of Utrecht

P0 Box 80198

Utrecht 3508 TD

The Netherlands

E-mail: d.j.j.heederik@uu.nl

Received:

June 072011

Accepted after revision:

June 112011

PROVENANCE

Submitted article, peer reviewed. 


\begin{tabular}{|c|c|c|c|c|}
\hline Control measure & Agent & Process/appliance & Working environment & Work practice \\
\hline Elimination & Total substitution & Different process & Layout change & $\begin{array}{l}\text { Automation, robotisation, } \\
\text { remote control }\end{array}$ \\
\hline Reduction & $\begin{array}{l}\text { Partial substitution, } \\
\text { change of form }\end{array}$ & $\begin{array}{c}\text { Adjustment, } \\
\text { preventive maintenance, } \\
\text { specialised appliance }\end{array}$ & Good housekeeping & $\begin{array}{l}\text { Correct work procedures, training, } \\
\text { instruction, motivation, supervision }\end{array}$ \\
\hline Isolation & & Enclosure segregation & $\begin{array}{c}\text { Glove box, safety cabinet, } \\
\text { segregation, high-exposure } \\
\text { departments }\end{array}$ & Ensuring enclosure \\
\hline Ventilation & & $\begin{array}{l}\text { Local exhaust ventilation, } \\
\text { push/pull ventilation }\end{array}$ & $\begin{array}{l}\text { Dilution ventilation, air douches, } \\
\text { air curtains }\end{array}$ & $\begin{array}{l}\text { Portable jets, low-volume, } \\
\text { high-velocity tools }\end{array}$ \\
\hline
\end{tabular}

Europe and the USA may also recommend exposure standards. However, few standards exist for allergens [1], and these standards may not always protect workers against development of disease.

\section{WHAT EVIDENCE IS AVAILABLE ON THE EFFECT OF PREVENTION?}

There are different levels of evidence on the effect of preventative measures in the work environment. While the effect of generic exposure control measures has been evaluated under experimental conditions, this will not be discussed further. A review on efficiency and efficacy is available [2], which describes the development and evaluation of an evidence database on the effectiveness of risk management measures to control inhalation exposure. There is some evidence for the effect of individual control measures on allergen exposure. Control measures have been studied in cross-sectional studies in which determinants of exposure are explored by comparing situations with and without the specific determinant. Fewer studies make use of before and after comparisons in which the effect of a control measure on exposure is followed over time. Optimally, the effect of control measures should be evaluated using randomised trials or crossover designs, as was attempted in a study on wood dust exposure in the state of Minnesota in the USA, in which 48 businesses were randomised to an intervention (written recommendations, technical assistance and worker training) or comparison (written recommendations alone) condition. The Minnesota Wood Dust Study exemplifies the complexity of primary intervention in the work environment, which should not be compared with clinical interventions $[3,4]$.

First, companies are heterogeneous with regard to industrial processes and, as a result, different approaches can or have to be chosen to realise similar exposure reductions. This makes the intervention process difficult to control. Interventions in the work environment are, therefore, usually referred to as pragmatic interventions.

Secondly, prevention interventions with the health effect as the critical end-point may ethically be difficult to defend, especially when the result can only be measured after several years of intervention. Withholding interventions from workers can create complex legal and ethical situations for physicians and researchers, as well as employers. Therefore, it makes more sense to intervene on the exposure, and use the exposure level as the outcome of interest. Health impact assessments may help define the intervention goals [5].

These points illustrate why the number of intervention studies based on randomised trials or even well-designed cohort or case-control studies is limited. Most interventions have been evaluated by exploring time trends for occupational allergy or asthma cases using disease registry data. This approach has the limitation that, while the number of cases might be accurate, the denominator (i.e. the population at risk from which the cases arise) is not well defined and may change over time.

From key question 5 in the guidelines on the management of work-related asthma [6], "What is the impact of controlling workrelated exposures to prevent asthma?", three sub-questions guided the review of existing literature on the primary prevention of occupational asthma.

5a) Is elimination or reduction of workplace exposures to allergens and irritants effective for primary prevention of occupational sensitisation and asthma? 5b) What is the effectiveness of reducing skin exposures to prevent occupational asthma? 5c) What is the effectiveness of PPE (masks, respirators and gloves) to prevent occupational sensitisation and asthma?

\section{METHODS}

The statements and recommendations formulated in this review are based on a systematic evaluation of the international literature according to the methods extensively described by BAUR et al. [6].

Search results as well as a list of considered articles were included in evidence tables and are presented in table $\mathrm{O} 3$ of the online supplementary material in the article by BAUR et al. [6].

\section{RESULTS}

The search, initially performed in June 2008, yielded 72 results. An updated search was performed in April 2010 and yielded six additional results, thus the final yield of our search was 78 references. The identified references were selected on the basis of the abstracts. This resulted in 16 remaining references 
described in the evidence tables. The literature search strategy for skin references yielded 44 results, but no references that specifically addressed the impact of reducing skin exposure. Abstracts for these 44 references were reviewed and 15 references were identified in which researchers evaluated skin exposure in workers at risk of developing occupational asthma or relevant review articles addressing occupational skin exposure and asthma. Additional references in this section were identified from articles cited by the selected articles.

The literature search for PPE yielded 77 results. We reviewed abstracts for the 77 references and identified 14 in which researchers tested respirators that were intended to control exposure to occupational asthma agents. One reference was excluded after review of the full text article revealed it was not appropriate. The remaining 13 articles were the basis for the text on the effectiveness of respirators for primary prevention.

\section{Is elimination or reduction of workplace exposures to allergens and irritants effective for primary prevention of occupational sensitisation and asthma?}

Exposure response studies

Numerous studies, mostly cross-sectional in nature, have examined relationships between exposure to allergens and the occurrence of sensitisation or work-related asthma. Exposure response studies support the concept that exposure reduction is likely to be followed by a reduction in disease burden. A positive dose-response relationship between exposure and sensitisation has been found in both experimental animal studies [7] and studies of workers exposed to allergens of high molecular weight (HMW) and low molecular weight, including wheat flour, fungal $\alpha$-amylase, laboratory animal allergens, organic acid anhydrides, isocyanates and platinum salts [8-20]. Some of these studies use variables known or likely to be associated with exposure level, such as duration of exposure or number of hours exposed per week. Others make use of more elaborate exposure assessment strategies, in which the exposure has been monitored by personal or area sampling equipment, followed by analysis of the allergen content of the dust sample. The latter approach facilitates the description of a quantitative exposure response relationship between measured exposure level and occurrence of sensitisation or asthma. Exposure response relationships indicate that implementation of primary preventive measures in the workplace that result in a reduction of exposure should also lead to a reduction in sensitisation rate.

\section{Exposure reduction studies}

What observations indicate that certain preventive measures lead to a reduction of exposure? The effect of few exposure reduction measures has been studied in practice. Thus, little is known about the effectiveness and efficacy of many possible exposure reduction measures. Studies have explored the effect on exposure of work tasks, cleaning and protective procedures, quality of ventilation systems and work routines in a range of different settings, such as bakeries [21-23], wood industries [24-27] and hairdressers [28]. However, these studies are usually cross-sectional and more exploratory in nature.

\section{Natural rubber latex}

Stronger evidence is shown in table 2, stratified by specific allergen. The most convincing example of the beneficial effects of an intervention is exposure to latex allergens. For latex, a meta-analysis is available that includes the separate studies described in table 2 [29]. Several studies explored differences in exposure levels between healthcare workers using powdered and non-powdered gloves. The most powerful study investigating the use of non-powdered gloves, which was associated with lower exposure, was a longitudinal case crossover intervention. In this study, introduction of powder-free, protein-poor natural rubber latex (NRL) gloves led to 10-fold lower aeroallergen exposure levels [31]. The effect of this single preventive measure on the prevalence or incidence of sensitisation and occupational asthma has been studied for NRL as well. A review of the literature in 2006 indicated that eight primary prevention intervention studies had been published on NRL exposure since 1990 [29], including the exposure study described previously [31]. All the studies in this review that explored disease as the outcome were observational studies that showed a decrease in sensitisation rates, either in a cross-sectional analysis or in a longitudinal design (both prospective and retrospective) [32, 34$36,39]$. These studies on latex form the largest evidence base of primary prevention studies for any occupational asthma. This study concluded that substitution of powdered latex gloves with low-protein, powder-free NRL gloves or latex-free gloves greatly reduces NRL aeroallergens, NRL sensitisation and NRL asthma in healthcare workers. None of the individual studies fulfilled strict criteria for good-quality intervention studies, i.e. they were observational studies without a randomised design. However, taken together, these studies support assertions that substitution of NRL greatly reduces NRL sensitisation and asthma. The studies evaluated as evidence in support of this statement were ranked Scottish Intercollegiate Guidelines Network (SIGN) level $2+$, meaning they were well-conducted, case-control or cohort studies with a low risk of confounding, bias or chance, and a moderate probability that the relationship is causal.

\section{Other asthma-inducing agents}

Fewer studies are available for asthma-inducing agents other than NRL. One example of a longitudinal exposure study is the study by MEIJSTER et al. [40], which explored the effect of control measures on dust and allergen exposure in a nonrandomised design. The authors found that changes in exposure over time varied substantially between sectors and jobs. For bakeries a modest downward annual trend in exposure of $-2 \%$ was found for flour dust and $-8 \%$ for fungal amylase. For flour mills the annual trend for flour dust was $-12 \%$, while no significant trend was observed for amylase. For ingredient producers, results were generally nonsignificant but indicated a reduction in flour dust exposure and increase in fungal $\alpha$-amylase exposure. A modest increase in use of control measures and proper work practices was reported in most sectors, especially the use of local exhaust ventilation and decreased use of compressed air. Few longitudinal studies like this one have been performed and most studies have not used experimental designs.

In other environments, studies have been undertaken with interventions comprising combinations of different preventive dust control measures, as well as education and PPE. During a 10-yr follow-up, SMITH [41] found a decrease in the annual incidence rates of symptomatic sensitisation to flour and fungal amylase in bakers from 2,085 per million to 405 per million employees per year (table 3). The intervention focused on 


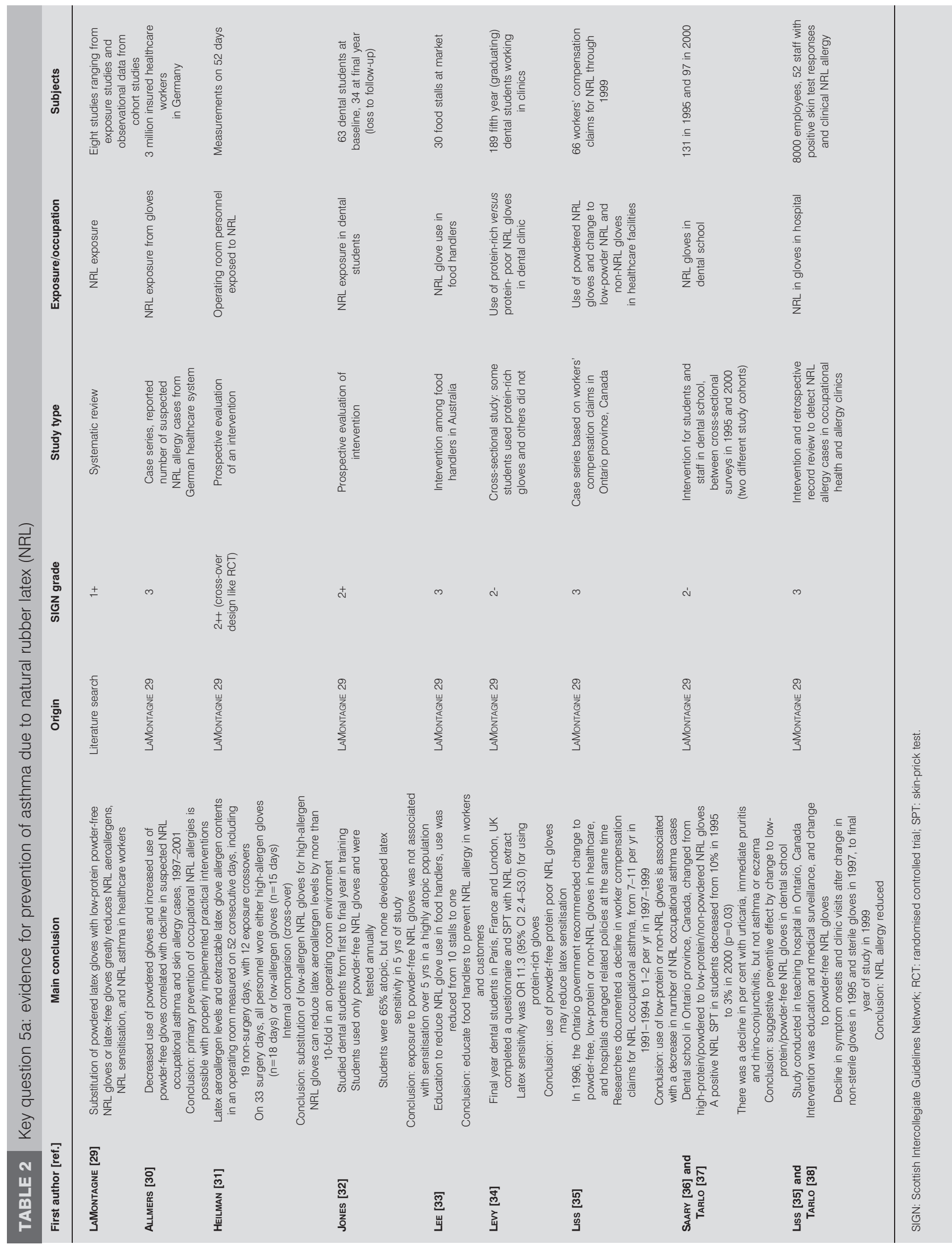


TABLE 3 Key question 5a: evidence for prevention of asthma due to a variety of agents

\begin{tabular}{|c|c|c|c|c|c|c|}
\hline & Main conclusion & Origin & SIGN grade & Study type & Exposure/occupation & Subjects \\
\hline \multicolumn{7}{|l|}{ Anhydrides } \\
\hline GRAMMER [42] & $\begin{array}{l}\text { Before introduction of respirators, annual } \\
\text { incidence for asthma was } 10 \% \\
\text { In } 7 \text { yrs of follow-up after respirators, } \\
\text { highest annual incidence was } 2 \% \\
\text { Conclusion: respirators can reduce incidence of } \\
\text { occupational asthma, in workers exposed to HHPA }\end{array}$ & $\begin{array}{l}\text { Literature } \\
\text { search }\end{array}$ & $2+$ & $\begin{array}{l}\text { Prospective cohort } \\
\text { study following } \\
\text { intervention } \\
\text { (introduction } \\
\text { of respirators) }\end{array}$ & HHPA & $\begin{array}{c}66 \text { new workers who } \\
\text { made HHPA }\end{array}$ \\
\hline \multicolumn{7}{|l|}{ Diisocyanates } \\
\hline TARLO [43] & $\begin{array}{c}\text { In } 1983, \text { Ontario, Canada mandated medical } \\
\text { surveillance programme for workers exposed } \\
\text { to diisocyanates, followed by retrospective } \\
\text { assessments to determine benefits } \\
\text { Frequency of diisocyanate asthma workers' } \\
\text { compensation claims (both number and percentage } \\
\text { of all occupational asthma claims) peaked in 1988, } \\
\text { and then declined in } 1993 \\
\text { Conclusion: medical surveillance programme contributed } \\
\text { to the positive change, but reduced diisocyanate } \\
\text { exposures and increased awareness of problem } \\
\text { by workers and physicians may have } \\
\text { also contributed to decline }\end{array}$ & $\begin{array}{l}\text { Literature } \\
\text { search }\end{array}$ & $\begin{array}{l}3 \text { for surveillance } \\
\text { and } 2+\text { for } \\
\text { case-control study } \\
\text { within } \\
\text { case series }\end{array}$ & $\begin{array}{c}\text { Registry based } \\
\text { ecological study } \\
\text { Case series from workers' } \\
\text { compensation claims } \\
\text { for occupational asthma } \\
\text { attributed to diisocyanates } \\
\text { in province of Ontario, } \\
\text { Canada }\end{array}$ & $\begin{array}{l}\text { Diisocyanate exposure } \\
\text { (study had exposure } \\
\text { above threshold limit } \\
\text { value as readout } \\
\text { parameter) }\end{array}$ & $\begin{array}{l}\text { Number of claims variec } \\
\text { by year, from } 55-58 \\
\text { claims per yr in 1988- } \\
\text { 1990, to 19-20 claims } \\
\text { per yr in 1992-1993 }\end{array}$ \\
\hline \multicolumn{7}{|l|}{$\begin{array}{l}\text { Flour and other } \\
\text { bakery exposure }\end{array}$} \\
\hline SMITH [41] & $\begin{array}{l}\text { The intervention reduced bread improver levels by } \\
\text { better exhaust ventilation, respiratory protection, education, } \\
\text { respiratory health surveillance and dust sampling } \\
\text { There was an overall reduction in the incidence of new } \\
\text { cases of symptomatic sensitisation, from } 2085 \text { per } \\
\text { million employees per yr in the first } 5 \text { yrs of the } \\
\text { surveillance programme, to } 405 \text { per million employees } \\
\text { per yr in the subsequent } 5 \text { yrs } \\
\text { Symptomatic sensitisation incidence was not related } \\
\text { to total inhalable dust levels } \\
\text { Conclusion: the strategy of targeting bread improver } \\
\text { exposure is an effective approach for preventing } \\
\text { symptomatic sensitisation in bread bakeries }\end{array}$ & $\begin{array}{l}\text { Literature } \\
\text { search }\end{array}$ & $2-$ & $\begin{array}{l}\text { Prospective intervention } \\
\text { in UK food company } \\
\text { Based on surveillance } \\
\text { data in combination } \\
\text { with a triage approach } \\
\text { that was not validated }\end{array}$ & $\begin{array}{l}\text { Bakery workers, flour } \\
\text { millers exposed to } \\
\text { flour and enzymes, } \\
\text { especially fungal } \\
\text { amylase }\end{array}$ & $\begin{array}{l}>3000 \text { workers per yea } \\
\text { under surveillance }\end{array}$ \\
\hline MEIJSTER [40] & $\begin{array}{c}\text { Changes in exposure over time varied } \\
\text { between sectors and jobs } \\
\text { For bakeries: modest downward trend of }-2 \% \\
\text { per yr for flour dust and }-8 \% \text { per yr for amylase } \\
\text { For flourmills: }-12 \% \text { per yr for flour dust and no } \\
\text { significant trend for amylase } \\
\text { For ingredient producers: results generally } \\
\text { nonsignificant, but indicated a reduction in flour } \\
\text { dust and increase in fungal } \alpha \text {-amylase } \\
\text { Modest increase in use of control measures } \\
\text { and proper work practices reported in most sectors, } \\
\text { especially local exhaust ventilation and decreased } \\
\text { use of compressed air } \\
\text { Conclusion: the magnitude of the observed } \\
\text { reductions in exposure levels indicates that } \\
\text { the sector-wide intervention strategy } \\
\text { implemented had a limited overall effect }\end{array}$ & $\begin{array}{l}\text { Literature } \\
\text { search }\end{array}$ & $2+$ & $\begin{array}{l}\text { Sector-wide intervention } \\
\text { programme, with education } \\
\text { on good work practices, } \\
\text { and nonrandomised before } \\
\text { and after evaluation of } \\
\text { exposure to wheat and } \\
\text { fungal } \alpha \text {-amylase }\end{array}$ & $\begin{array}{l}\text { Bakery workers, flour } \\
\text { millers, bakery } \\
\text { ingredient workers }\end{array}$ & $\begin{array}{l}1770 \text { personal exposure } \\
\text { measurements generally } \\
\text { including data on } \\
\text { flour dust and fungal } \\
\alpha \text {-amylase levels, taken } \\
\text { in four surveys (1993, } \\
2001,2005 \text { and 2007) }\end{array}$ \\
\hline \multicolumn{7}{|l|}{ Detergent enzymes } \\
\hline CATHCART [44] & $\begin{array}{l}\text { At five production facilities in the UK dust and } \\
\text { enzymes levels in 1969-1993, lung function of } \\
\text { workers in 1972-1991, and cases of occupational } \\
\text { asthma in 1968-1992 were evaluated } \\
\text { Exposure groups were defined by job history } \\
\text { Enzyme levels declined over the study period } \\
\text { Changes in FEV1 and FVC showed no consistent } \\
\text { trends in relation to enzyme exposure } \\
\text { The annual number of cases of enzyme } \\
\text { allergy and asthma declined }\end{array}$ & $\begin{array}{l}\text { Literature } \\
\text { search }\end{array}$ & $2-$ & $\begin{array}{l}\text { Registry-based study, } \\
\text { case series, } \\
\text { ecological }\end{array}$ & $\begin{array}{c}\text { Detergent enzyme } \\
\text { exposure in } \\
\text { production } \\
\text { facilities }\end{array}$ & 731 male workers \\
\hline SCHWEIGERT [45] & $\begin{array}{l}\text { Variety of controls introduced across detergent } \\
\text { enzyme manufacturing industry } \\
\text { Decrease in number of occupational asthma } \\
\text { cases in Latin American and North American } \\
\text { detergent enzyme manufacturing sites in } \\
\text { 1969-1998, but no denominators indicated }\end{array}$ & $\begin{array}{l}\text { Literature } \\
\text { search }\end{array}$ & 4 & $\begin{array}{l}\text { Review article with } \\
\text { minimal data and } \\
\text { documentation }\end{array}$ & $\begin{array}{l}\text { Detergent enzyme } \\
\text { manufacturing } \\
\text { industry }\end{array}$ & Unclear \\
\hline \multicolumn{7}{|l|}{$\begin{array}{l}\text { Laboratory animal } \\
\text { allergy and asthma }\end{array}$} \\
\hline ВотНАм [46] & $\begin{array}{c}\text { Prospectively studied incidence of allergy to } \\
\text { laboratory animals in } 383 \text { workers exposed } \\
\text { to rodents and to rabbits } \\
\text { Intervention was introduction of a site order } \\
\text { and code of practice for working with animals, } \\
\text { and an education programme } \\
\text { Concurrent with the intervention, incidence of allergy } \\
\text { after } 1 \text { yr of exposure to animals fell from } 37 \% \text { in } \\
1980-1981 \text { to } 20 \% \text { in } 1982,10 \% \text { in } 1983 \text { and } 12 \% \\
\text { in } 1984 \\
\text { Atopy increased risk of allergy in first year of exposure } \\
\text { but not in second or third years of exposure }\end{array}$ & $\begin{array}{l}\text { Literature } \\
\text { search }\end{array}$ & $2-$ & $\begin{array}{l}\text { Intervention study with } \\
\text { longitudinal, repeated } \\
\text { measurements }\end{array}$ & $\begin{array}{l}\text { Laboratory animal } \\
\text { workers with } \\
\text { exposure to } \\
\text { rodents and } \\
\text { rabbits }\end{array}$ & 383 workers \\
\hline
\end{tabular}




\begin{tabular}{|c|c|c|c|c|c|c|}
\hline & Main conclusion & Origin & SIGN grade & Study type & Exposure/occupation & Subjects \\
\hline FISHER [47] & $\begin{array}{l}\text { Intervention programme included education, } \\
\text { engineering controls, administrative controls, use of } \\
\text { personal protective equipment, and medical surveillance } \\
\text { Prospective survey of } 5 \text { yrs of data to determine } \\
\text { effect programme (1991-1995) } \\
\text { At the start of the programme, prevalence of laboratory } \\
\text { animal allergy was } 12-22 \% \text {, and then } 0 \% \text { in the last } \\
2 \text { yrs of the } 5 \text {-yr observation period } \\
\text { Conclusion: laboratory animal allergy is preventable } \\
\text { through the implementation of a comprehensive effort } \\
\text { to reduce exposure to allergens }\end{array}$ & $\begin{array}{l}\text { Literature } \\
\text { search }\end{array}$ & $2-$ & $\begin{array}{l}\text { Comprehensive } \\
\text { intervention programme } \\
\text { with longitudinal, } \\
\text { repeated } \\
\text { measurements }\end{array}$ & $\begin{array}{c}\text { Laboratory animal } \\
\text { workers }\end{array}$ & 159 employees \\
\hline
\end{tabular}

SIGN: Scottish Intercollegiate Guidelines Network; HHPA: hexahydrophthalic anhydride; FEV1: forced expiratory volume in 1 s; FVC: forced vital capacity.

information and training, installation of local exhaust ventilation, and wearing of respirators during handling of powdered bread improvers. No exposure data was included. Dissemination of information about exposure limits of diisocyanates to public (health) authorities in Ontario, Canada, together with a primary preventive programme and health surveillance, probably resulted in lower exposure levels and a decrease in accepted claims over time. TARLO et al. [43] retrospectively assessed workers compensation data from 1980 to 1993 and found an initial increase in compensation claims, which were attributed to increased case findings due to the medical surveillance programme. The subsequent $50 \%$ decrease in accepted claims from 1991 to 1992-1993 was attributed to a combination of primary and secondary prevention measures. When measured levels of diisocyanate were compared among companies who had compensated claims for occupational asthma with companies without accepted claims, the former were more likely to have had measured levels of diisocyanates $>0.005$ ppm [43].

In the detergent industry, the introduction of work practices and a medical surveillance programme decreased sensitisation rates to enzymes among workers within almost 20 yrs [45]. Significant reductions in the prevalence of occupational asthma have been reported after introducing granulated proteases [44, 48]. In the study of CATHCART et al. [44], during the observation period, atmospheric enzyme concentrations and the reported incidence of enzyme asthma fell considerably. However, the number of cases dropped, but the denominator, consisting of the number of individuals at risk, was not established. So, it is unclear if the risk for an individual declined. It cannot be excluded that the number of workers exposed declined over the years because of mechanisation and automation of production processes. CULLINAN et al. [49] reported an outbreak of asthma in a detergent factory which exclusively used encapsulated enzymes, while sensitisation rate was related to exposure level. A recent study showed a similar outbreak but in an enzyme factory using liquid enzyme formulations [50].

In laboratory animal workers allergy, a preventative programme including education, engineering and administrative controls, the use of respirators and medical surveillance showed a decrease in the incidence rate of asthma from $10 \%$ to $0 \%$ during a 5 -yr followup [47]. However, this study was not designed as a cohort study, there was considerable loss to follow-up and forms of selection bias such as the healthy worker effect cannot be excluded. In addition, the effectiveness of the intervention to reduce allergen exposures was not evaluated. In a retrospectively assembled cohort of new employees working with laboratory animals, an education programme may have contributed to the decrease in annual incidence rate of laboratory animal allergy from $42 \%$ to $15 \%$ over 4 yrs $[46,47]$. Comparison of the symptom prevalence in each entry year for each new cohort entering the workforce indicates a lower prevalence in cohorts that entered after the start of the intervention. However, trends over time cannot be interpreted because the occurrence of laboratory animal allergy was not explored by considering the proportion exposed and not expressed as a rate with person-time of follow-up in the denominator. Loss to follow-up was considerable, and the risk of developing laboratory animal allergy from year to year is likely to have been underestimated as a result. It is unclear if the apparent reduction in laboratory animal allergy occurrence was accompanied by a reduction in allergen levels since no allergen exposure data was obtained.

\section{What is the effectiveness of reducing skin exposures to prevent occupational asthma?}

To our knowledge there are no studies that address whether reducing skin exposure to occupational allergens can prevent occupational asthma. Elimination of the exposure, the preferred approach to preventing occupational asthma, reduces all routes of exposure, including skin exposure.

Concern that skin exposure to chemical allergens and even possibly to HMW protein allergens may increase asthma risk has arisen based on several lines of "evidence", including clinical experience and case reports, animal studies, and limited epidemiological findings. Animal studies have clearly demonstrated that skin exposure to chemical allergens, such as isocyanates, can induce type 2 helper T-cell-like sensitisation and subsequent airway inflammation following inhalation challenge [51]. Of note, skin exposure can be more effective than inhalation exposure at inducing sensitisation, and lower skin sensitising doses more effective than higher doses in producing asthmatic responses [52-54].

\section{Assessment of skin exposure}

To assess whether human skin exposure to allergens increases asthma risk requires methods to sample and quantify skin exposure. Such methods are not as well developed and not as widely available as airborne exposure methods. Skin exposure assessment is further complicated by factors such as the frequently sporadic nature of skin exposure, uncertainty about skin uptake, unknown effectiveness of protective clothing, mixed exposures, and the challenge of separating the risks of skin versus inhalational exposures. Despite these challenges, investigators have recently quantified isocyanate skin exposures in exposed workers using 


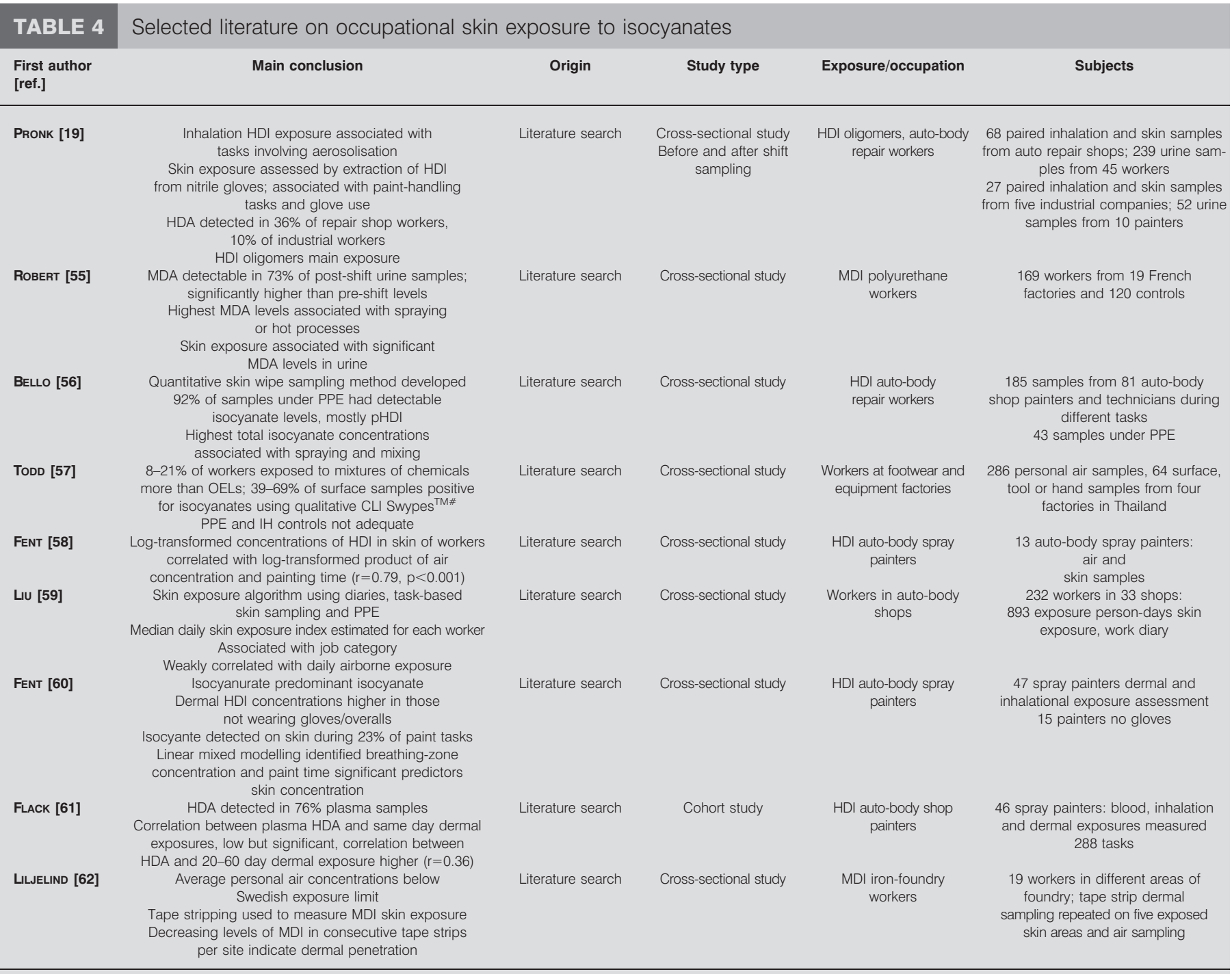

HDI: hexamethylene diisocyanate; HDA: hexamethylene diamine; MDA: methylenedianiline diisocyanate; MDI: methylene diphenyl diisocyante; PPE: personal protective equipment; pHDI: polymeric HDI isocyanate; OEL: occupational exposure limit; IH: industrial hygiene. ${ }^{\#}$ : skin wipes that provide a visible indication of skin exposure (Colorimetric Laboratories, Inc., Plaines, IL, USA).

novel sampling and analytical approaches, including skin surface wipe sampling, skin tape stripping, and sampling of inner gloves and pads under PPE (table 4) [56, 58, 60-63]. Analysis of consecutive skin tape strips has documented dermal penetration of isocyanate, and correlations between isocyanate skin exposure and urinary metabolites support skin uptake [60-62]. These studies have also demonstrated frequent isocyanate skin exposure among workers in several work settings despite the use of standard PPE, such as gloves $[56,60,63]$. They have also demonstrated that while in some work settings skin and respiratory exposures are highly correlated, in others settings they are not, potentially enabling the differentiation of skin and respiratory health effects. Incorporation of skin exposure metrics into epidemiological studies of exposed workers should enable investigators to better define the risks of skin exposure and also the effectiveness of industrial hygiene controls, including protective clothing, to reduce such exposures.

\section{Isocyanate skin exposure and asthma}

To date, the evidence that human skin exposure to allergens can increase the risk of asthma comes primarily from case reports of isocyanate asthma or sensitisation in settings where isocyanate skin contact has been reported or suspected, and where airborne isocyanate levels are very low (table 5). Most of these cases have involved workplace exposure to methylene diphenyl diisocyanate (MDI), which is much less volatile than the other commonly used isocyanates, and is frequently handled as a liquid, creating greater opportunity for exposure through skin contamination than through inhalation. To date, the primary epidemiological study that addressed the risk of asthma related to occupational skin exposure was a crosssectional and 1-yr follow-up study of 214 newly employed workers in a wood manufacturing plant that used MDI resins [64]. Skin exposure was assessed by a questionnaire regarding skin staining, MDI on clothes and type of work. $27 \%$ of workers in areas with high potential for liquid MDI exposure reported new-onset asthma-like symptoms versus $0 \%$ in low-potential areas. Skin staining and MDI on clothes, and working around and cleaning up MDI was associated with new asthma-like symptoms. Air monitoring data (six personal breathing zone samples) showed no detectable MDI and a single glove wipe 


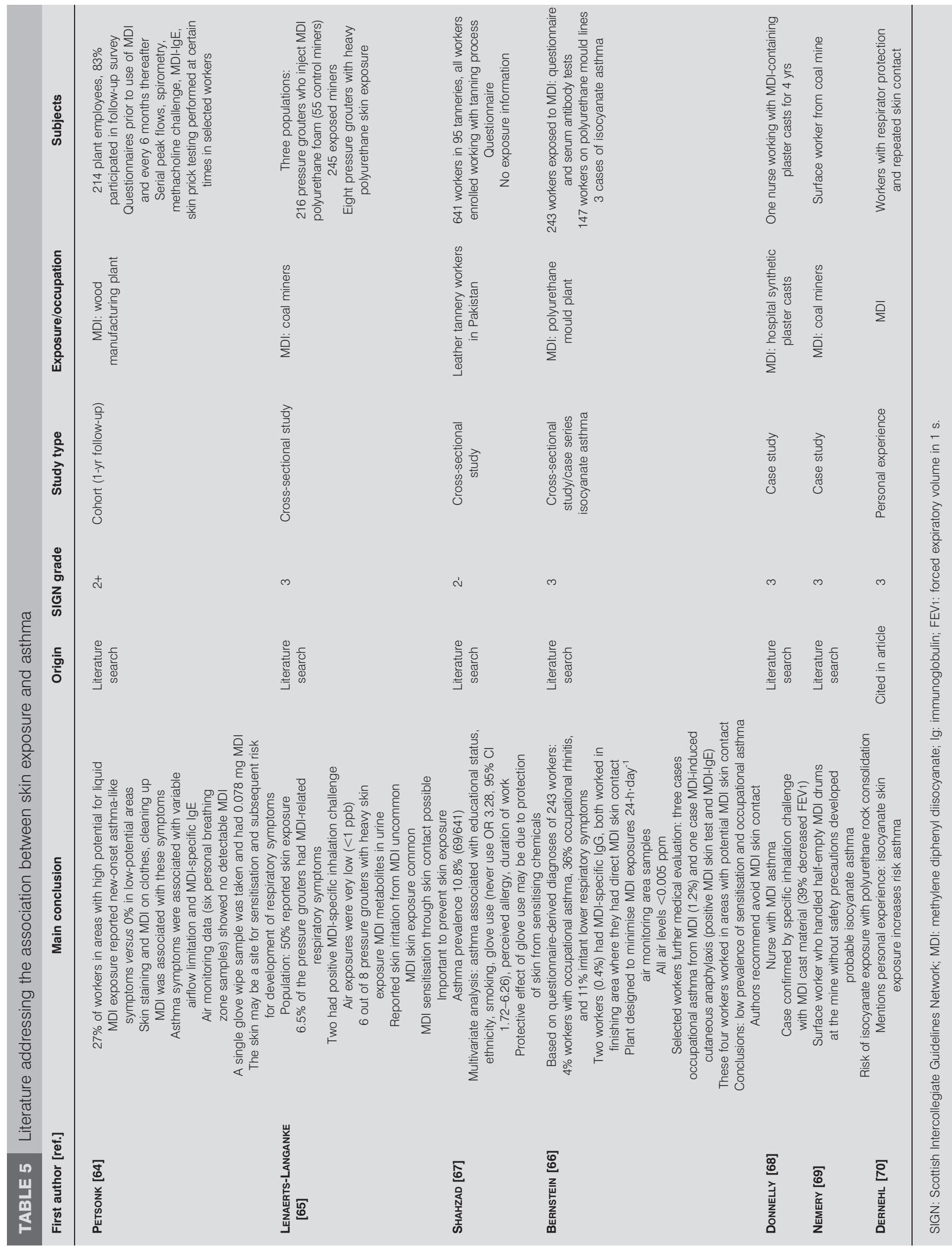


sample that was taken had $0.078 \mathrm{mg}$ of MDI. The authors concluded that skin might be a site for potential immunological sensitisation and subsequent risk for development of respiratory symptoms. In other studies, an investigation of approximately 500 coal miners who injected MDI for rock consolidation identified about 15 workers with a diagnosis of occupational asthma or sensitisation (positive MDI-immunoglobulin (Ig)E) [65]. Air sampling for MDI was reported to show very low levels $(<1 \mathrm{ppb})$ and MDI skin exposure was reported to occur commonly among these workers. The authors concluded that isocyanate skin exposure probably contributed to MDI sensitisation and asthma [65]. Surveillance of 243 workers exposed to MDI in a polyurethane mould plant with MDI air levels consistently $<0.005 \mathrm{ppm}$ identified three cases of MDI asthma and one case of MDI-induced cutaneous anaphylaxis [66]. In one case the onset of asthma symptoms occurred after an MDI spill. All four workers were reported to work in areas with potential for skin contact with uncured MDI.

Studies among other groups of workers are also very limited. A cross-sectional study of 641 tannery workers found an asthma prevalence of $10.8 \%$ [67]. Multiple regression analysis showed the strongest risk factor for asthma was not using gloves (OR 3.28, 95\% CI 1.72-6.26), with educational status, ethnicity, smoking, perceived allergy and duration of work also being significant risk factors (table 5).

Several studies have provided data on the effectiveness of currently recommended PPE in preventing skin exposure to isocyanates. Although typically lower amounts are noted than on unprotected skin, isocyanate has been detected underneath latex and nitrile gloves, cartridge respirators and protective clothing $[56,60,63]$.

In summary, skin exposure to certain occupational asthmainducing agents probably increases the risk of occupational asthma, despite limited epidemiological studies to date. The contribution of skin exposure to asthma risk probably varies greatly with different allergenic exposures, work processes and settings, as well as other factors than can alter skin barrier function. Dose-response relationships with allergens frequently are nonlinear, and there are insufficient data to identify safe skin exposure levels for sensitisers. There are data indicating that currently recommended PPE may not be effective in limiting skin exposure to isocyanate chemicals in some settings. Improved skin exposure methodologies should facilitate the incorporation of skin exposure assessment into epidemiology studies to better define exposure risk factors and also help evaluate the effectiveness of preventive interventions. In the meantime, it would be prudent to increase awareness of the potential risks of allergen skin exposure and to limit such exposures.

\section{What is the effectiveness of PPE to prevent occupational sensitisation and asthma?}

PPE and the hierarchy of controls

In the hierarchy of controls for occupational health hazards, eliminating or minimising exposures at the source or in the environment is considered more effective than the worker using PPE [71]. The success of respiratory personal protection requires an ongoing commitment by employers and employees to a programme that includes selection, cleaning, maintenance and storage of equipment, as well as training, fit testing and medical monitoring of users. Respirators are best used as an interim measure while efforts to control exposures at the source or in the environment are being implemented, or when controls at these other levels are not possible. Perhaps, since respirators are not considered an optimal way to control exposures, they have often been used in conjunction with other control activities at the source and/or environmental level. Such comprehensive programmes that include the use of respirators have been implemented for workers exposed to laboratory animals [47, 72-74], dusts and fumes in aluminium production [75], diisocyanates [76] and disinfectants [76, 77]. While many of these programmes have reported success at prevention, it is not possible to determine the contribution made by respirators alone.

\section{Previous statements from professional organisations}

Two recent statements from professional organisations address use of respirators for primary prevention of work-related asthma. An expert panel convened by the American College of Chest Physicians (ACCP) produced a publication on the diagnosis and management of work-related asthma [78]. This document advises primary prevention by controlling exposures to known workplace sensitisers and irritants, briefly citing a variety of methods, including respirators. The examples of using respirators to control exposures involved exposure to hexahydrophthalic anhydride (HHPA) [79] and isocyanates [80]. The British Occupational Health Research Foundation (BOHRF) also developed guidelines for occupational asthma [81]. Similar to the ACCP document, the BOHRF guidelines emphasise reducing airborne exposures to occupational asthma agents. The advice specific to respiratory protective equipment (RPE) was: "The use of RPE reduces the incidence of, but does not completely prevent, occupational asthma" [81]. The evidence cited included the same article used in the ACCP document for HHPA [79] and two references for control of exposure to isocyanates $[64,82]$ not cited by the ACCP.

\section{Indirect evidence for effectiveness of PPE in preventing occupational asthma}

An updated review of the medical literature revealed indirect evidence that use of respiratory protective devices might prevent asthma onset, by demonstrating that respirators can reduce exposures to agents that can cause occupational asthma. These studies investigated: air purifying respirators [83] and half-face respirators with particulate/organic vapour/formaldehyde filters [84] used by firefighters; air purifying respirators [85], half-mask respirators with frequent cartridge changes [86], and half-face air purifying or full-face air-supplied respirators [87] for workers exposed to styrene; hood style supplied air respirators used to reduce exposure to chromium and other materials during sanding in aircraft manufacturing [88]; P2 facemasks and fresh-air helmets to reduce levels of rodent allergens among laboratory animal handlers [89]; and certified two-tie protective masks that reduced total particle concentrations by $97 \%$ in swine confinement buildings [90].

This indirect evidence takes on somewhat more significance for agents that have a positive dose-response relationship with occupational asthma, since a reduction in exposure should decrease the number of cases. Such a relationship has been reported for wheat allergen [91], and investigators compared exposure levels measured inside a P2 particle filter facemask to 
TABLE 6 Evidence for effectiveness of respirators to prevent onset of occupational asthma

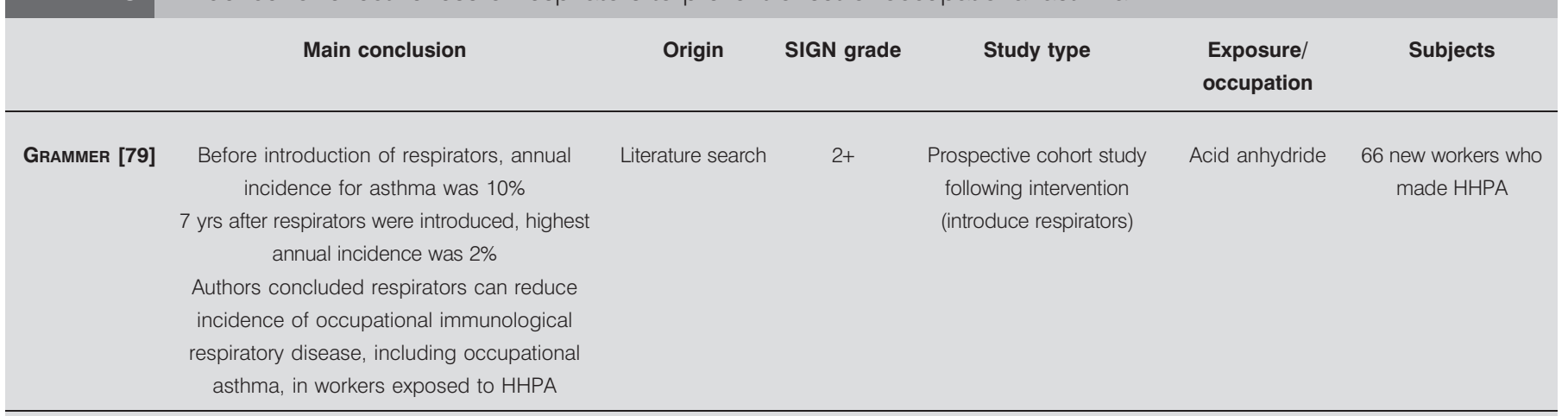

SIGN: Scottish Intercollegiate Guidelines Network; HHPA: hexahydrophthalic anhydride.

measurements taken outside the facemask [92]. Exposure levels were reduced by $93-96 \%$ using the facemasks, and the investigators concluded that these respirators might help to prevent baker's asthma.

Several studies have examined the effectiveness of respiratory protective devices intended to limit isocyanate exposure in paint operations. A study of 22 spray painters working in automobile body shops measured isocyanates both inside and outside negative pressure, air-purifying half-face piece respirators with organic vapour cartridges and paint pre-filters [80]. The authors concluded that these respirators provided reasonably effective protection if the workers were trained and fit tested. In a study conducted in a test chamber, air purifying respirators with organic vapour cartridges were, on average, 99.4\% efficient based on comparisons of isocyanate exposures inside and outside the respirators [93]. In another study of spray painters, researchers concluded that air-fed visors provided good protection if they were well maintained and the airflow was sufficiently high [94].

\section{Direct evidence for effectiveness of PPE in preventing} occupational asthma

Despite the encouraging findings that respirators can substantially reduce exposures to asthma agents, these studies did not directly test whether respirator use is associated with a decline in the onset of occupational asthma. The two studies for isocyanates and respirators in the BOHRF guidelines at least suggest such a benefit. In one study, automobile body shop employees who applied paints containing isocyanates were approximately one-third as likely to have occupational asthma symptoms if they used a positive pressure respirator [82]. However, a relatively small number of participants used this respirator and the finding was not statistically significant [82]. A second study provided evidence that inconsistent use of respiratory protection might have negative consequences. Specifically, isocyanate-exposed workers at a wood products plant were at greater risk for new-onset asthma-like symptoms if they removed their respirators even briefly $(p<0.05)$ [64].

A more direct investigation of the value of respiratory protection for primary prevention was conducted among workers who were manufacturing an epoxy resin that required HHPA (table 6) [79]. This is the same study cited in both the ACCP and BOHRF documents. Study participants were offered a choice of three different respirators: a disposable dust and mist respirator, a half-face organic vapour respirator, or a full-face organic vapour respirator. The highest annual incidence for asthma over the $7 \mathrm{yrs}$ of follow-up was $2 \%$, compared to approximately $10 \%$ that was observed in employees before the 
introduction of respirators. There was no statistically significant difference between respirators, but none of the workers who wore the full-face respirators developed occupational asthma, even those who worked in high-exposure jobs.

\section{Conclusion}

There is little direct evidence in the literature that respirators are effective for primary prevention of occupational asthma. Additional studies are needed, especially for settings in which other controls are not possible.

\section{DISCUSSION}

Based on the review of the literature as already summarised, we arrived at the following statements, recommendations and comments on future research.

\section{Statements}

The strength of the evidence for each statement was graded according to the three-star system of the Royal College of General Practitioners (RCGP), which includes the quality and the quantity of the evidence (*: limited; **: moderate; ***: strong), as previously described [95].

Complete elimination of the exposure is the most straightforward approach to reducing the burden of disease associated with occupational allergy and asthma. (**).

It is extremely likely that exposure reduction will lead to a reduction of the disease burden for occupational asthma, as indicated by exposure-response relationships. However, there is limited evidence provided by a few ecological and surveillance studies. $\left(^{*}\right)$.

Substitution of NRL greatly reduces NRL sensitisation and the occurrence of NRL-related asthma. $\left.{ }^{* * *}\right)$.

Skin exposure to allergens occurs in the workplace, but there is limited evidence that skin exposure contributes to the onset of occupational sensitisation and asthma. RCGP: limited evidence mainly provided by case reports and cross-sectional studies. $\left({ }^{*}\right)$.

Use of respiratory protective equipment can contribute to primary prevention of occupational asthma. $\left(^{*}\right)$.

\section{Recommendations}

The recommendations are detailed in table 7 .

\section{Future aspects}

In general, studies that make use of strong analytical designs, such as randomised controlled trials and controlled intervention studies, are potentially possible for allergen exposure. Observational studies that focus on disease occurrence in relation to exposure have limitations. Exposure studies focusing on the evaluation of allergen exposures and exposure interventions are strongly encouraged. More evidence is needed for all types of preventive actions, including improved ventilation, education of workers, changes in work organisation, and use of different types of PPE.

There is a need to further explore the role of skin exposure in relation to development of sensitisation and disease occurrence. Additional research is needed to demonstrate the effectiveness of primary preventive measures on allergen exposure and occurrence of allergy and asthma.

\section{SUPPORT STATEMENT}

The work of the Task Force on the Management of Work-related Asthma was funded by the European Respiratory Society. The findings and conclusions in this report are those of the author and do not necessarily represent the views of the National Institute for Occupational Safety and Health.

\section{STATEMENT OF INTEREST}

None declared.

\section{ACKNOWLEDGEMENTS}

The members of the Task Force are as follows. X. Baur (Chair: Institute for Occupational and Maritime Medicine, University Medical Center Hamburg-Eppendorf, Hamburg, Germany); T. Sigsgaard (Co-Chair: Århus University, Institute of Environmental and Occupational Medicine, School of Public Health, Århus C, Denmark); T.B. Aasen (Haukeland University Hospital, Bergen, Norway); P.S. Burge (Heart of England NHS Foundation Trust, Dept Respiratory Medicine, Birmingham, UK); H. Dressel (Städt. Klinikum München GmbH Klinikum Neuperlach Zentrum für Akutgeriatrie und Frührehabilitation, Munich, Germany); D. Heederik (Environmental Epidemiology Division, Institute for Risk Assessment Sciences (IRAS), University of Utrecht, Utrecht, the Netherlands); P.K. Henneberger (National Institute for Occupational Safety and Health, Centers for Disease Control and Prevention, Morgantown, WV, USA); P. Maestrelli (Dept of Environmental Medicine and Public Health, University of Padova, Padova, Italy); C.A. Redlich (Yale University, Occupational and Environmental Medicine Program, New Haven, CT, USA); J. Rooyackers (Netherlands Expertise Center for Occupational Respiratory Disorders - NECORD IRAS NKAL, Utrecht, the Netherlands); V. Schlünssen (Århus Universitet, Århus C, Denmark); O. Vandenplas (Dept of Chest Medicine, Mont-Godinne Hospital, Université Catholique de Louvain, Yvoir, Belgium); D. Wilken (Institute for Occupational and Maritime Medicine, University Medical Center Hamburg-Eppendorf, Hamburg, Germany).

\section{REFERENCES}

1 Rijnkels JM, Smid T, Van den Aker EC, et al. Prevention of workrelated airway allergies; summary of the advice from the Health Council of the Netherlands. Allergy 2008; 63: 1593-1596.

2 Fransman W, Schinkel J, Meijster T, et al. Development and evaluation of an exposure control efficacy library (ECEL). Ann Occup Hyg 2008; 52: 567-575.

3 Lazovich D, Parker DL, Brosseau LM, et al. Effectiveness of a worksite intervention to reduce an occupational exposure: the Minnesota wood dust study. Am J Public Health 2002; 92: 1498-1505.

4 Brosseau LM, Parker DL, Lazovich D, et al. Designing intervention effectiveness studies for occupational health and safety: the Minnesota Wood Dust Study. Am J Ind Med 2002; 41: 54-61.

5 Meijster T, Warren N, Heederik D, et al. What is the best strategy to reduce the burden of occupational asthma and allergy in bakers? Occup Environ Med 2011; 68: 176-182.

6 Baur X, Sigsgaard T, Aasen TB, et al. Guidelines for the management of work-related asthma. Eur Respir J 2012; 39: 529-545.

7 Arts JH, Mommers C, de Heer C. Dose-response relationships and threshold levels in skin and respiratory allergy. Crit Rev Toxicol 2006; 36: 219-251.

8 Brooks SM, Edwards JJ, Apol A, et al. An epidemiologic study of workers exposed to western red cedar and other wood dusts. Chest 1981; 80: Suppl. 1, 30-32.

9 Cullinan P, Cook A, Gordon S, et al. Allergen exposure, atopy and smoking as determinants of allergy to rats in a cohort of laboratory employees. Eur Respir J 1999; 13: 1139-1143.

10 Heederik D, Venables KM, Malmberg P, et al. Exposure-response relationships for work-related sensitization in workers exposed to 
rat urinary allergens: results from a pooled study. J Allergy Clin Immunol 1999; 103: 678-684.

11 Houba R, Heederik D, Doekes G. Wheat sensitization and workrelated symptoms in the baking industry are preventable. An epidemiologic study. Am J Respir Crit Care Med 1998; 158: 1499-1503.

12 Houba R, Heederik DJ, Doekes G, et al. Exposure-sensitization relationship for alpha-amylase allergens in the baking industry. Am J Respir Crit Care Med 1996; 154: 130-136.

13 Kruize H, Post W, Heederik D, et al. Respiratory allergy in laboratory animal workers: a retrospective cohort study using preemployment screening data. Occup Environ Med 1997; 54: 830-835.

14 Meredith SK, Bugler J, Clark RL. Isocyanate exposure and occupational asthma: a case-referent study. Occup Environ Med 2000; 57: 830-836.

15 Nieuwenhuijsen MJ, Heederik D, Doekes G, et al. Exposureresponse relations of alpha-amylase sensitisation in British bakeries and flour mills. Occup Environ Med 1999; 56: 197-201.

16 Nieuwenhuijsen MJ, Putcha V, Gordon S, et al. Exposure-response relations among laboratory animal workers exposed to rats. Occup Environ Med 2003; 60: 104-108.

17 Ott MG. Occupational asthma, lung function decrement, and toluene diisocyanate (TDI) exposure: a critical review of exposureresponse relationships. Appl Occup Environ Hyg 2002; 17: 891-901.

18 Peretz C, de Pater N, de Monchy J, et al. Assessment of exposure to wheat flour and the shape of its relationship with specific sensitization. Scand J Work Environ Health 2005; 31: 65-74.

19 Pronk A, Preller L, Raulf-Heimsoth M, et al. Respiratory symptoms, sensitization, and exposure response relationships in spray painters exposed to isocyanates. Am J Respir Crit Care Med 2007; 176: 1090-1097.

20 Schlunssen V, Schaumburg I, Heederik D, et al. Indices of asthma among atopic and non-atopic woodworkers. Occup Environ Med 2004; 61: 504-511.

21 Bulat P, Myny K, Braeckman L, et al. Exposure to inhalable dust, wheat flour and alpha-amylase allergens in industrial and traditional bakeries. Ann Occup Hyg 2004; 48: 57-63.

22 Burdorf A, Lillienberg L, Brisman J. Characterization of exposure to inhalable flour dust in Swedish bakeries. Ann Occup Hyg 1994; 38: 67-78.

23 Meijster T, Tielemans E, de Pater N, et al. Modelling exposure in flour processing sectors in the Netherlands: a baseline measurement in the context of an intervention program. Ann Occup Hyg 2007; 51: 293-304.

24 Alwis U, Mandryk J, Hocking AD, et al. Dust exposures in the wood processing industry. Am Ind Hyg Assoc J 1999; 60: 641-646.

25 Friesen MC, Davies HW, Teschke K, et al. Predicting historical dust and wood dust exposure in sawmills: model development and validation. J Occup Environ Hyg 2005; 2: 650-658.

26 Scheeper B, Kromhout H, Boleij JS. Wood-dust exposure during wood-working processes. Ann Occup Hyg 1995; 39: 141-154.

27 Schlunssen V, Jacobsen G, Erlandsen M, et al. Determinants of wood dust exposure in the Danish furniture industry - results from two cross-sectional studies 6 years apart. Ann Occup Hyg 2008; 52: 227-238.

28 Hollund BE, Moen BE. Chemical exposure in hairdresser salons: effect of local exhaust ventilation. Ann Occup Hyg 1998; 42: 277-282.

29 LaMontagne AD, Radi S, Elder DS, et al. Primary prevention of latex related sensitisation and occupational asthma: a systematic review. Occup Environ Med 2006; 63: 359-364.

30 Allmers H, Schmengler J, Skudlik C. Primary prevention of natural rubber latex allergy in the German health care system through education and intervention. J Allergy Clin Immunol 2002; 110: 318-323.

31 Heilman DK, Jones RT, Swanson MC, et al. A prospective, controlled study showing that rubber gloves are the major contributor to latex aeroallergen levels in the operating room. J Allergy Clin Immunol 1996; 98: 325-330.
32 Jones KP, Rolf S, Stingl C, et al. Longitudinal study of sensitization to natural rubber latex among dental school students using powder-free gloves. Ann Occup Hyg 2004; 48: 455-457.

33 Lee A, Nixon R, Frowen K. Reduction of use of latex gloves in food handlers: an intervention study. Contact Dermatitis 2001; 44: 75-79.

34 Levy D, Allouache S, Chabane MH, et al. Powder-free protein-poor natural rubber latex gloves and latex sensitization. JAMA 1999; 281: 988.

35 Liss GM, Tarlo SM. Natural rubber latex-related occupational asthma: association with interventions and glove changes over time. Am J Ind Med 2001; 40: 347-353.

36 Saary MJ, Kanani A, Alghadeer $\mathrm{H}$, et al. Changes in rates of natural rubber latex sensitivity among dental school students and staff members after changes in latex gloves. J Allergy Clin Immunol 2002; 109: 131-135.

37 Tarlo SM, Sussman GL, Holness DL. Latex sensitivity in dental students and staff: a cross-sectional study. J Allergy Clin Immunol 1997; 99: 396-401.

38 Tarlo SM, Easty A, Eubanks K, et al. Outcomes of a natural rubber latex control program in an Ontario teaching hospital. J Allergy Clin Immunol 2001; 108: 628-633.

39 Cadot P, Tits G, Bussels L, et al. Asthma and hand dermatitis to leek. Allergy 2001; 56: 192-193.

40 Meijster T, Tielemans E, Heederik D. Effect of an intervention aimed at reducing the risk of allergic respiratory disease in bakers: change in flour dust and fungal alpha-amylase levels. Occup Environ Med 2009; 66: 543-549.

41 Smith TA. Preventing baker's asthma: an alternative strategy. Occup Med (Lond) 2004; 54: 21-27.

42 Grammer LC, Ditto AM, Tripathi A, et al. Prevalence and onset of rhinitis and conjunctivitis in subjects with occupational asthma caused by trimellitic anhydride (TMA). J Occup Environ Med 2002; 44: 1179-1181.

43 Tarlo SM, Liss GM, Yeung KS. Changes in rates and severity of compensation claims for asthma due to diisocyanates: a possible effect of medical surveillance measures. Occup Environ Med 2002; 59: 58-62.

44 Cathcart M, Nicholson P, Roberts D, et al. Enzyme exposure, smoking and lung function in employees in the detergent industry over 20 years. Medical Subcommittee of the UK Soap and Detergent Industry Association. Occup Med (Lond) 1997; 47: 473-478.

45 Schweigert MK, Mackenzie DP, Sarlo K. Occupational asthma and allergy associated with the use of enzymes in the detergent industry - a review of the epidemiology, toxicology and methods of prevention. Clin Exp Allergy 2000; 30: 1511-1518.

46 Botham PA, Davies GE, Teasdale EL. Allergy to laboratory animals: a prospective study of its incidence and of the influence of atopy on its development. Br J Ind Med 1987; 44: 627-632.

47 Fisher R, Saunders WB, Murray SJ, et al. Prevention of laboratory animal allergy. J Occup Environ Med 1998; 40: 609-613.

48 Juniper CP, Roberts DM. Enzyme asthma: fourteen years' clinical experience of a recently prescribed disease. J Soc Occup Med 1984; 34: 127-132.

49 Cullinan P, Harris JM, Newman Taylor AJ, et al. An outbreak of asthma in a modern detergent factory. Lancet 2000; 356: 1899-1900.

50 van Rooy FG, Houba R, Palmen N, et al. A cross-sectional study among detergent workers exposed to liquid detergent enzymes. Occup Environ Med 2009; 66: 759-765.

51 Redlich CA. Skin exposure and asthma: is there a connection? Proc Am Thorac Soc 2010; 7: 134-137.

52 Ban M, Morel G, Langonne I, et al. TDI can induce respiratory allergy with Th2-dominated response in mice. Toxicology 2006; 218: $39-47$.

53 Herrick CA, Xu L, Wisnewski AV, et al. A novel mouse model of diisocyanate-induced asthma showing allergic-type inflammation in the lung after inhaled antigen challenge. J Allergy Clin Immunol 2002; 109: 873-878. 
54 Pauluhn J. Brown Norway rat asthma model of diphenylmethane-4, 4'-diisocyanate (MDI): analysis of the elicitation dose-response relationship. Toxicol Sci 2008; 104: 320-331.

55 Robert A, Ducos P, Francin JM, et al. Biological monitoring of workers exposed to $4,4^{\prime}$-methylenediphenyl diisocyanate (MDI) in 19 French polyurethane industries. Int Arch Occup Environ Health 2007; 80: 412-422.

56 Bello D, Redlich CA, Stowe MH, et al. Skin exposure to aliphatic polyisocyanates in the auto body repair and refinishing industry: II. A quantitative assessment. Ann Occup Hyg 2008; 52: 117-124.

57 Todd LA, Mottus K, Mihlan GJ. A survey of airborne and skin exposures to chemicals in footwear and equipment factories in Thailand. J Occup Environ Hyg 2008; 5: 169-181.

58 Fent KW, Jayaraj K, Ball LM, et al. Quantitative monitoring of dermal and inhalation exposure to 1,6-hexamethylene diisocyanate monomer and oligomers. J Environ Monit 2008; 10: 500-507.

59 Liu Y, Stowe MH, Bello D, et al. Skin exposure to aliphatic polyisocyanates in the auto body repair and refinishing industry: III. A personal exposure algorithm. Ann Occup Hyg 2009; 53: 33-40.

60 Fent KW, Trelles Gaines LG, Thomasen JM, et al. Quantification and statistical modeling-part II: dermal concentrations of monomeric and polymeric 1,6-hexamethylene diisocyanate. Ann Occup Hyg 2009; 53: 691-702.

61 Flack SL, Fent KW, Trelles Gaines LG, et al. Quantitative plasma biomarker analysis in HDI exposure assessment. Ann Occup Hyg 2010; 54: 41-54.

62 Liljelind I, Norberg C, Egelrud L, et al. Dermal and inhalation exposure to methylene bisphenyl isocyanate (MDI) in iron foundry workers. Ann Occup Hyg 2010; 54: 31-40.

63 Pronk A, Yu F, Vlaanderen J, et al. Dermal, inhalation, and internal exposure to 1,6-HDI and its oligomers in car body repair shop workers and industrial spray painters. Occup Environ Med 2006; 63: 624-631.

64 Petsonk EL, Wang ML, Lewis DM, et al. Asthma-like symptoms in wood product plant workers exposed to methylene diphenyl diisocyanate. Chest 2000; 118: 1183-1193.

65 Lenaerts-Langanke H. Isocyanat-bedingte Atemwegserkrankungen bei Bergleuten [Isocyanate-induced respiratory disease in coal miners]. Zbl Arbeitsmedizin 1992; 42: 2-25.

66 Bernstein DI, Korbee L, Stauder T, et al. The low prevalence of occupational asthma and antibody-dependent sensitization to diphenylmethane diisocyanate in a plant engineered for minimal exposure to diisocyanates. J Allergy Clinical Immunol 1993; 92: 387-396.

67 Shahzad K, Akhtar S, Mahmud S. Prevalence and determinants of asthma in adult male leather tannery workers in Karachi, Pakistan: a cross sectional study. BMC Public Health 2006; 6: 292.

68 Donnelly R, Buick JB, Macmahon J. Occupational asthma after exposure to plaster casts containing methylene diphenyl diisocyanate. Occup Med (Lond) 2004; 54: 432-434.

69 Nemery B, Lenaerts L. Exposure to methylene diphenyl diisocyanate in coal mines. Lancet 1993; 341: 318.

70 Dernehl CU. Health hazards associated with polyurethane foams. J Occup Med 1966; 8: 59-62.

71 Weeks JL, Levy BS, Wagner GR. Preventing occupational disease and injury. Washington, American Public Health Association, 1991.

72 Goodno LE, Stave GM. Primary and secondary allergies to laboratory animals. J Occup Environ Med 2002; 44: 1143-1152.

73 Sjostedt L, Willers S, Orbaek P, et al. A seven-year follow-up study of lung function and methacholine responsiveness in sensitized and non-sensitized workers handling laboratory animals. J Occup Environ Med 1998; 40: 118-124.

74 Vanhanen M, Tuomi T, Tiikkainen U, et al. Risk of enzyme allergy in the detergent industry. Occup Environ Med 2000; 57: 121-125.

75 Sorgdrager B, de Looff AJ, de Monchy JG, et al. Occurrence of occupational asthma in aluminum potroom workers in relation to preventive measures. Int Arch Occup Environ Health 1998; 71: 53-59.
76 Pisati G, Baruffini A, Zedda S. Toluene diisocyanate induced asthma: outcome according to persistence or cessation of exposure. Br J Ind Med 1993; 50: 60-64.

77 Fujita H, Sawada Y, Ogawa M, et al. [Health hazards from exposure to ortho-phthalaldehyde, a disinfectant for endoscopes, and preventive measures for health care workers]. Sangyo Eiseigaku Zasshi 2007; 49: 1-8.

78 Tarlo SM, Balmes J, Balkissoon R, et al. Diagnosis and management of work-related asthma: American College of Chest Physicians Consensus Statement. Chest 2008; 134: 1-41.

79 Grammer LC, Harris KE, Yarnold PR. Effect of respiratory protective devices on development of antibody and occupational asthma to an acid anhydride. Chest 2002; 121: 1317-1322.

80 Liu Y, Stowe MH, D B, et al. Respiratory protection from isocyanate exposure in the autobody repair and refinishing industry. J Occup Environ Hyg 2006; 3: 234-249.

81 Nicholson PJ, Cullinan P, Taylor AJ, et al. Evidence based guidelines for the prevention, identification, and management of occupational asthma. Occup Environ Med 2005; 62: 290-299.

82 Cullen MR, Redlich CA, Beckett WS, et al. Feasibility study of respiratory questionnaire and peak flow recordings in autobody shop workers exposed to isocyanate-containing spray paint: observations and limitations. Occup Med (Lond) 1996; 46: 197-204.

83 Currie J, Caseman D, Anthony TR. The evaluation of CBRN canisters for use by firefighters during overhaul. Ann Occup Hyg 2009; 53: 523-538.

84 De Vos AJ, Cook A, Devine B, et al. Effect of protective filters on fire fighter respiratory health during simulated bushfire smoke exposure. Am J Ind Med 2006; 49: 740-750.

85 Triebig G, Werner P, Zimmer H. A field study to determine the effectiveness of several respiratory protection masks on the styrene exposure during lamination activities. Ind Health 2009; 47: 145-154.

86 Nakayama S, Nishide T, Horike T, et al. Evaluation of the efficiency of respiratory protective equipment based on the biological monitoring of styrene in fibreglass reinforced plastics industries. J Occup Health 2004; 46: 132-140.

87 Lof A, Brohede C, Gullstrand E, et al. The effectiveness of respirators measured during styrene exposure in a plastic boat factory. Int Arch Occup Environ Health 1993; 65: 29-34.

88 Janssen L, Bidwell J, Cuta K, et al. Workplace performance of a hoodstyle supplied-air respirator. J Occup Environ Hyg 2008; 5: 438-443.

89 Renstrom A, Karlsson AS, Tovey E. Nasal air sampling used for the assessment of occupational allergen exposure and the efficacy of respiratory protection. Clin Exp Allergy 2002; 32: 1769-1775.

90 Pickrell JA, Heber AJ, Murphy JP, et al. Total and respirable dust in swine confinement buildings: the benefit of respiratory protective masks and effect of recirculated air. Vet Hum Toxicol 1995; 37: 430-435.

91 Brisman J, Jarvholm B, Lillienberg L. Exposure-response relations for self reported asthma and rhinitis in bakers. Occup Environ Med 2000; 57: 335-340.

92 Renstrom A, Mattsson ML, Blidberg K, et al. Nasal air sampling for measuring inhaled wheat allergen in bakeries with and without facemask use. J Occup Environ Med 2006; 48: 948-954.

93 Dharmarajan V, Lingg RD, Myer HE. Evaluation of organic-vapor respirator cartridge efficiency for hexamethylene diisocyanate vapor in the presence of organic solvents. Appl Occup Environ Hyg 2001; 16: 397-404.

94 Bolsover J, Rajan-Sithamparanadarajah B, Vaughan N. Workplace protection of air-fed visors used in paint spraying operations. Ann Occup Hyg 2006; 50: 219-229.

95 The Royal College of General Practitioners. The Development and Implementation of Clinical Guidelines. Report of the Clinical Guidelines Working Group. London, RCGP, 1995.

96 Atkins D, Best D, Briss PA, et al. Grading quality of evidence and strength of recommendations. BMJ 2004; 328: 1490. 